\title{
Near-infrared spectrometry: the future of renal graft perfusion monitoring?
}

\author{
Štěpán Malýa , Jakub Křístek ${ }^{\mathrm{a}, \mathrm{b}}$, Libor Janoušek ${ }^{\mathrm{a}}$, Jiří Froněk ${ }^{\mathrm{a}, \mathrm{b}}$, Róbert Novotnýa
}

a Transplant Surgery Department, Institute for Clinical and Experimental Medicine, Prague

${ }^{b}$ Department of Anatomy, 2nd Faculty of Medicine, Charles University in Prague, Prague

\section{ARTICLE INFO}

Article history:

Submitted: 5. 2. 2021

Accepted: 11. 2. 2021

Available online: 9. 8. 2021

\section{Kličová slova:}

Infračervený

Monitorování

Perfuze

Renální spektrometrie

Transplantát

\section{SOUHRN}

Cévní komplikace představují jednu z hlavních komplikací transplantace ledvin (renal transplantation, RTx). Cévní komplikace, $k$ níž dojde $v$ prvních několika hodinách nebo dnech po RTx, může závažným způsobem ohrozit funkci renálního štěpu (renal graft, RG), a dokonce vést $k$ jeho ztrátě. Blízká infračervená spektrometrie (near-infrared spectrometry, NIRS), s jejiź pomocí se měří perfuze RG a saturace kyslíkem, představuje nově se prosazující a perspektivní diagnostickou metodu. Podle různých studií korelují výsledky parametrů NIRS v reálném čase s výsledky parametrů vyšetření RG dopplerovským ultrazvukem (DU). Vzhledem $\mathrm{k}$ dalšímu technickému pokroku $\mathrm{v}$ této oblasti by se NIRS mohla stát $\mathrm{v}$ budoucnu zlatým standardem pro monitorování RG a případně nahradit metodu DU. Metoda NIRS by rovněž mohla vyloučit nepřesnosti a diskrepance $s$ výsledky DU, připisované na konto lékaře-operátora jako lidského faktoru, tedy zkušenosti personálu provádějíííno vyšetření DU renálního štěpu.

(c) 2021, ČKS.
Keywords:

Infrared

Monitoring

Perfusion

Renal spectrometry

Transplant

\section{ABSTRACT}

Vascular complications are one of the major complications in renal transplantation (RTx). Early vascular complication occurring within a few hours or days after RTx can severely compromise renal graft (RG) function and can even lead to a transplanted renal graft (RG) loss. Near-infrared spectrometry (NIRS) measuring of RG perfusion and oxygen saturation is a newly emerging and promising diagnostic procedure. Based on various studies, real-time NIRS parameters correlate with Doppler's ultrasonography (DU) RG parameters. With further advancements in technology, NIRS has a very high chance of becoming a gold standard in the monitoring of renal transplants in the future and potentially replacing today's Doppler ultrasonography. Furthermore, NIRS will potentially eliminate the inaccuracies and discrepancies caused by a physician-operating factor when compared to DU, i.e. the experience of the staff performing the DU examination of RG.

\section{Review}

Renal transplantation (RTx) is the treatment of choice for patients with the end-stage renal disease with the offering of improved quality of life relative to dialysis. ${ }^{1}$ Vascular complications after RTx are still one of the major concerns with an incidence ranging from 1-9\% accompanied by increased morbidity and mortality. ${ }^{2,3}$ Early vascular complication occurring within a few hours or days after RTx can severely compromise graft function and can even lead to a transplanted renal graft (RG) loss. ${ }^{4}$ The causes of the various vascular complications in renal transplants are multifactorial: technical errors, recipient-related factors such as atherosclerosis and decreased cardiac output. Arterial or vein thrombosis is the leading cause of these events usually occurring due to technical problem besides hyper-acute rejection or thrombophilia. ${ }^{5}$ Vascular complications occur more frequently in grafts from deceased donors from living donors. ${ }^{6}$ Therefore, periprocedural/early postoperative monitoring after RTx is essential to prevent RG damage or even graft loss.

To date, the monitoring of graft perfusion has been achieved through a comprehensive evaluation of clinical indicators, biochemical markers, and Doppler ultrasonography (DU). Clinical indicators and biochemical markers have a low negative predictive value with low accuracy in predicting vascular complications. DU is an accurate method for evaluating blood flow in RG. However, its 
reproducibility is significantly physician dependent. Furthermore, it does not allow for continuous RG perfusion monitoring. ${ }^{7}$

Over the past years, several ultrasound-based techniques had emerged such as tissue stiffness assessment and contrast-enhanced ultrasonography assessing the renal micro-vascularisation. New ultrasensitive Doppler techniques improve the detection of slow blood flow and can be used alone or after administration of contrast agents. Regardless of these improvements in ultrasonography, DU still remains the gold standard in non-invasive RG monitoring after RTx up to date. ${ }^{8,9}$ With the advancements in technology, new technical procedures are finding their way into clinical practice.

Near-infrared (NIRS) spectroscopy had shown a great potential in paediatric as well as adult RTx. NIRS is a real-time, non-invasive technique for monitoring tissue oxygenation. In general, most biological tissue is relatively transparent to infrared light in the range closest to the visual spectrum (700-1,000 nm). All NIRS devices emit light in the near-infrared spectrum and analyse photons returning to the transducer..$^{10}$ The physiological principle is the detection of a change in the spectrum of infrared light reflected from the tissue depends on the relative concentration of oxygenated and deoxygenated haemoglobin.

The major advantage of NIRS is the ability to predict hypoxia-induced tissue damage sooner than venous saturation or lactate. ${ }^{9,11}$ Renal time oxygen saturation is a reliable predictor for acute kidney injury and is a precise marker of acute kidney hypoperfusion. ${ }^{9,12}$ NIRS can differentiate RG dysfunction caused by hypoperfusion arising from vascular complication or suboptimal circulatory haemodynamic parameters. ${ }^{13}$

It is believed that the depth of an organ measured from the skin surface has an effect on the oxygen saturation measurement accuracy. ${ }^{14}$ The proposed maximum depth for accurate oxygen saturation measurement by Epstein et al. is $8 \mathrm{~cm} .{ }^{11}$ Malakasioti et al. demonstrated that within the proposed maximum depth of the RG measured from the skin, no significant difference in tissue oxygenation index between the upper and lower poles of RG is observed. This supports the feasibility of NIRS monitoring across patients of different age, body habitus for RG placement. ${ }^{13}$ The reproducibility of NIRS measurements can be significantly increased with the use of different channels for monitoring. ${ }^{15}$

Application of NIRS is early post-RTx period for evaluation of oxygen adequacy at a microvascular level. The sensitivity of NIRS for cortical blood flow greatly exceeds DU. DU has very limited application beyond arcuate vessels which reduces an early detection of early intrarenal involvement. ${ }^{16}$ This is particularly useful in paediatric RTx, where an adult kidney is transplanted. Large volumes of intravenous fluid and inotropes are used to ensure RG perfusion, both of which can result in adverse effects if not implemented carefully. ${ }^{17}$ Renal oximetry values in paediatric patients after RTx with delayed graft function are similar to those from recipients with good function. Thus, NIRS values play a crucial role in differentiating perfusion related causes of graft dysfunction. ${ }^{18}$ This caused some researchers to believe that NIRS could be used in the postoperative period in paediatric patients as a guide to fluid management decisions. ${ }^{14}$ The reproducibility of oxygen saturation of the RG plays a significant role in paediatric patients due to the specifications mentioned above and nuances associated with adult kidney placed in a paediatric patient. ${ }^{15}$

As every new emerging technical innovation with application in medicine, research on animal models is necessary fortis future advancements and development. There is a limited number of papers assessing optical measuring methods with applications in renal oxygen perfusion monitoring. ${ }^{19}$ Vaughan demonstrated that if tissue's strong light scattering is not taken into account, only the qualitative estimates of the changes in oxygenation are measured. ${ }^{20}$ The study by Krause et al. used a commercially available reflection spectrometer to monitor relative changes of haemoglobin per tissue volume and oxygen saturation in haemoglobin in the renal cortex of rats upon administration of contrast agents. ${ }^{21}$ Grosenic et al. showed in an experimental rat model significantly faster detection of renal hypo-perfusion by NIRS than by DU while simulating renal artery or vein occlusion. ${ }^{22}$ The latest experimental work involving NIRS as RG perfusion monitoring by Maly et al. demonstrated the feasibility and reproducibility with $100 \%$ sensitivity of NIRS for renal transplant perfusion monitoring in swine renal auto-transplantation experimental model when detecting a decreasing RG perfusion. ${ }^{23}$

\section{Conclusion}

NIRS measuring of RG perfusion and oxygen saturation is a newly emerging and promising diagnostic procedure. Based on various studies, real-time NIRS parameters correlate with DU RG parameters. With further advancements in technology, NIRS has a very high chance of becoming a gold standard in the monitoring of renal transplants in the future and potentially replacing today's Doppler ultrasonography. Furthermore, NIRS will potentially eliminate the inaccuracies and discrepancies caused by a physician-operating factor when compared to $D U$, i.e. the experience of the staff performing the DU examination of RG.

\section{Acknowledgements}

The author would like to thank to doc. MUDr. Jiři Froněk, Ph.D., FRCS, and doc. MUDr. Libor Janoušek, Ph.D., FEBS, Transplant Surgery Department, Institute for Clinical and Experimental Medicine, Prague, Czech Republic for providing their opinions in this research project.

\section{Conflict of interest}

The authors declare that there is no conflict of interests regarding the publication of this article.

\section{Funding body}

This research received no specific grant from any funding agency in the public, commercial, or not-for-profit sectors. 


\section{References}

1. Abecassis M, Bartlett ST, Collins AJ, et al. Kidney transplantation as primary therapy for end-stage renal disease: a National Kidney Foundation/Kidney Disease Outcomes Quality Initiative (NKF/KDOQITM) conference. Clin J Am Soc Nephrol 2008;3:471-480.

2. Ayvazoglu Soy EH, Akdur A, Kirnap M, et al. Vascular Complications After Renal Transplant: A Single-Center Experience. Exp Clin Transplant 2017;15(Suppl 1):79-83.

3. Tavakkoli M, Zafarghandi RM, Taghavi R, et al. Immediate Vascular Complications After Kidney Transplant: Experience from 2100 Recipients. Exp Clin Transplant 2017;15:504-508.

4. Tavakkoli M, Zafarghandi RM, Taghavi R, et al. Immediate Vascular Complications After Kidney Transplant: Experience from 2100 Recipients. Exp Clin Transplant 2017;15:504-508.

5. Srivastava A, Kumar J, Sharma S, et al. Vascular complication in live related renal transplant: An experience of 1945 cases. Indian J Urol 2013;29:42-47.

6. Salehipour M, Salahi H, Jalaeian $\mathrm{H}$, et al. Vascular complications following 1500 consecutive living and cadaveric donor renal transplantations: a single center study. Saudi J Kidney Dis Transpl 2009;20:570-572.

7. Baxter GM. Ultrasound of renal transplantation. Clin Radiol 2001;56:802-818.

8. Jimenez C, Lopez MO, Gonzalez E, et al. Ultrasonography in kidney transplantation: values and new developments. Transplant Rev 2009;23:209-213.

9. Correas JM, Anglicheau D, Joly D, et al. Ultrasound-based imaging methods of the kidney-recent developments. Kidney Int 2016;90:1199-1210.

10. Amigoni A, Mozzo E, Brugnaro L, et al. Four-side near-infrared spectroscopy measured in a paediatric population during surgery for congenital heart disease. Interact Cardiovasc Thorac Surg 2011;12:707-712.

11. Epstein CD, Haghenbeck KT. Bedside assessment of tissue oxygen saturation monitoring in critically ill adults: an integrative review of the literature. Crit Care Res Pract 2014;2014:709683.

12. Gist KM, Kaufman J, da Cruz EM, et al. A Decline in Intraoperative Renal Near-Infrared Spectroscopy Is Associated
With Adverse Outcomes in Children Following Cardiac Surgery. Pediatr Crit Care Med 2016;17:342-349.

13. Malakasioti G, Marks SD, Watson T, et al. Continuous monitoring of kidney transplant perfusion with near-infrared spectroscopy. Nephrol Dial Transplant 2018;33:1863-1869.

14. Ortmann LA, Fontenot EE, Seib PM, et al. Use of near-infrared spectroscopy for estimation of renal oxygenation in children with heart disease. Pediatr Cardiol 2011:32:748-753.

15. Hyttel-Sorensen S, Sorensen LC, Riera J, Greisen G. Tissue oximetry: a comparison of mean values of regional tissue saturation, reproducibility and dynamic range of four NIRS-instruments on the human forearm. Biomed Opt Express 2011;2:3047-3057.

16. Aschwanden M, Thalhammer C, Schaub S, et al. Renal vein thrombosis after renal transplantation - early diagnosis by duplex sonography prevented fatal outcome. Nephrol Dial Transplant 2006;21:825-826.

17. Taylor K, Kim WT, Maharramova M, et al. Intraoperative management and early postoperative outcomes of pediatric renal transplants. Paediatr Anaesth 2016;26:987-991.

18. Vidal E, Amigoni A, Brugnolaro V, et al. Near-infrared spectroscopy as continuous real-time monitoring for kidney graft perfusion. Pediatr Nephrol 2014;29:909-914.

19. Scully CG, Mitrou N, Braam B, et al. Detecting physiological systems with laser speckle perfusion imaging of the renal cortex. Am J Physiol Regul Integr Comp Physiol 2013;304:R929R939.

20. Vaughan DL, Wickramasinghe YA, Russell GI, et al. Near infrared spectroscopy: blood and tissue oxygenation in renal ischemia-reperfusion in rats. Int J Angiol 1995;4:25-30

21. Krause W, Muschick $P$, Krüger $U$. Use of near-infrared reflection spectroscopy to study the effects of X-ray contrast media on renal tolerance in rats: effects of a prostacyclin analogue and of phosphodiesterase inhibitors. Invest Radiol 2002;37:698-705.

22. Grosenick D, Cantow K, Arakelyan K, et al. Detailing renal hemodynamics and oxygenation in rats by a combined nearinfrared spectroscopy and invasive probe approach. Biomed Opt Express 2015;6:309-323.

23. Maly $S$, Janousek $L$, Bortel $R$, et al. NIRS-based monitoring of kidney graft perfusion. PloS One 2020;15:e0243154. 